\title{
Study of disease phenotype and its association with prognosis of paediatric inflammatory bowel disease in China
}

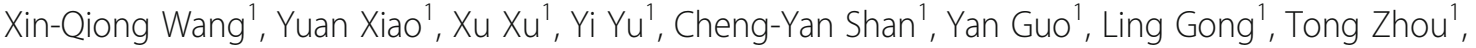 \\ Shen-Shen Gao ${ }^{2}$, Yao-Zong Yuan ${ }^{3}$, Xiao-Jin Wang ${ }^{4}$ and Chun-Di Xu, ${ }^{1,2^{*}}$ (D)
}

\begin{abstract}
Background: To investigate the unique features of inflammatory bowel disease (IBD) in children, we wanted to identify whether there might be a strong correlation between the disease phenotype and its prognosis at various ages in paediatric patients.

Methods: We collected data from patients diagnosed with IBD (ulcerative colitis (UC) or Crohn's disease (CD)) from 2002 to 2016. The diagnosis was made according to the Porto criteria and Paris Classification. Patient characteristics, clinical manifestations and treatments were collected. Risk factors for surgery, mortality and relapse were analysed by Cox proportional hazard models.

Results: Of the 143 patients, 113 had CD, and 30 had UC; there were 89 males and 54 females with a median age of 9 years (y). Thirteen patients in the $0-2$ y group were identified as having mutations in IL-10 receptor $A$, and this mutation was significantly more common in this age group than in 3-9 and 10-16 y patients. The risk factor for surgery was the B3 phenotype; risk factors for death were age 0-2 y and B3 phenotype; 0-2 y, B3 phenotype and steroid dependency were risk factors for early relapse.

Conclusions: Clinical manifestations of the onset of IBD in infants and toddlers were extensive and aggressive and were closely associated with early relapse and death. It is of particular interest that some of these patients developed IBD due to monogenic disorders; thus, introduction of genetic testing is essential for these patients.
\end{abstract}

Keywords: Inflammatory bowel disease, Children, Infantile or toddler onset IBD, Paris classification, Prognosis

\section{Background}

Inflammatory bowel disease (IBD) includes Crohn's disease (CD) and ulcerative colitis (UC); IBD-unclassified (IBD-U) is a group of chronic gastrointestinal inflammatory diseases. Approximately $25 \%$ of patients manifest with the disease in childhood or adolescence [1]. Our previous studies have indicated that the morbidity of paediatric IBD has been rapidly increasing in China over the past three decades [2]. Studies have also shown that paediatric IBD manifests as an extensive and aggressive

\footnotetext{
* Correspondence: chundixu55@163.com

'Department of Paediatrics, Ruijin Hospital, Shanghai Jiao Tong University,

School of Medicine, No. 197, Rui Jin Er Road, Shanghai 200025, China

${ }^{2}$ Department of Paediatrics, Ruijin Hospital North, Shanghai Jiao Tong

University, School of Medicine, Shanghai 201821, China

Full list of author information is available at the end of the article
}

disease $[3,4]$. However, further study suggested that the clinical manifestations and prognosis varied greatly in patients with various onset ages [5]. In our study, the paediatric Paris classification released in 2013 was used, as it is valuable for paediatric IBD studies [6]. Using the Paris classification, we further sub-classified IBD patients into two groups, A1a (0-10 y) and A1b (10-17 y). We also focused on the children with very early onset IBD (VEO-IBD), including infantile and toddler onset IBD, as infantile IBD might be partially linked to monogenic diseases such as defects in IL-10 or its receptors, Wiskott-Aldrich Syndrome, XIAP deficiency, leukocyte adhesion deficiencies, CD40L deficiency, IPEX syndrome and several others [7-9]. The clinical manifestations and phenotypes in this group of patients were different from those of patients in other age groups. However, it 
remains controversial as to whether these patients with monogenic diseases phenotype should be classified as having IBD $[9,10]$.

Because the clinical manifestations and phenotypes vary in IBD children, the prognosis of IBD is remarkably different in patients of different ages, and there is a lack of long-term follow-up studies on the natural course of the disease. In the current study, the natural course of disease was recorded with long-term follow-up to define the features and progression of paediatric IBD in China.

\section{Methods}

Medical records were retrospectively selected from the Department of Paediatrics, Ruijin hospital and North Ruijin Hospital; patients were diagnosed as having UC, CD, or IBD-U from January 2002 to September 2016. As a paediatric IBD centre, patients suspected of having IBD were recorded and followed up. The diagnosis was confirmed by at least three gastrointestinal (GI) paediatricians after complete physical examination, endoscopy, pathological examination, and radiological imaging determinations. The diagnosis was made according to the Porto criteria and Paris classification $[6,11,12]$. Complex patients with unclear diagnosis were re-evaluated by a multi-disciplinary team (MDT) of IBD professionals, consisting of GI paediatricians, radiologists, nutritionists, surgeons, nurses and adult gastroenterologists. Once the diagnosis was confirmed, the patients were followed up at the outpatient department regularly, and some patients were admitted to hospital for further treatment if necessary. A well-trained administrative staff was assigned to collect, document and store all the data.

There were 200 patients primarily reviewed. Fourteen diagnosed as having IBD-U could not be precisely classified until final follow-up and were therefore excluded from this study. Thirty-two patients with a follow-up period of less than 6 months were also excluded; however, the 11 patients who died within 6 months after diagnosis were included. Another 11 patients with incomplete medical records or without reports of endoscopy or imaging examination were excluded as well. Finally, there were 143 patients included in this study. All were less than 17 years old at the time of diagnosis. The patients were classified into three groups according to their age at diagnosis: $0-2,3-9$ and $10-16$ years old groups. Clinical information and laboratory tests were collected at diagnosis and at each follow-up.

\section{Genetic workup}

Twenty-four patients with onset before 3 years old had a genetic test (20 in the $0-2$ y group and 4 in the $3-10$ y group). Thirteen patients were involved in a previously published study that tested for 10 genes [13]; three of these had subsequent whole exome sequencing (WES).
The other 10 patients with VEO-IBD were further suggested to undertake genetic tests, comprising of more than 50 genes $[14,15]$ that were closely related to VEO-IBD (medical exome sequencing). In addition, parents were verified by Sanger sequencing if any positive finding was detected in the IBD children. One 5 -year-old patient was confirmed as having glycogen storage disease (GSD) Ib prior to IBD diagnosis.

\section{Disease activity index and definition of other evaluation indexes}

Disease activity was assessed by the Paediatric Crohn's Disease Activity Index (PCDAI) for patients with CD [16], and the Paediatric Ulcerative Colitis Activity Index (PUCAI) for patients with UC [17]. Patients with PUCAI $\geq 65$ were classified as having severe disease according to the Paris classification. In terms of disease progression, the duration between diagnosis and first relapse after clinical remission was recorded for each patient. A patient was defined as being in clinical remission if the disease activity index was $<10$ after induction therapy until the last follow-up, whereas a patient was defined as not in remission or relapse if the disease activity index was $\geq 10$ with symptoms after induction therapy. Steroid dependency was defined as a patient receiving more than $10 \mathrm{mg} / \mathrm{d}$ prednisolone for more than 3 months or clinical relapses were seen within 3 months of tapering steroids. Patients starting biological agents early after diagnosis were regarded as receiving "top-down" treatment.

\section{Growth and developmental index}

Height and weight were two important factors that were routinely recorded at primary diagnosis as well as at subsequent follow-up examinations in order to monitor physical growth and development; the index score was calculated by the Z-scoring method based on the national survey on growth of children under 7 years of age in nine cities of China in 2005 [18]. $Z<-2$ for weight at primary diagnosis and follow-up examination was recorded, and growth impairment (G1) was defined by the criteria of the Paris classification [6].

\section{Statistical analysis}

Discrete variables are expressed as numbers and percentages. Quantitative variables of normal distribution were expressed as the mean \pm standard deviation (SD). Data was analysed by t-test and chi-squared test to compare categorical data between different age groups. Quantitative variables of skewed distribution were expressed as median and interquartile range and compared by Kruskal-Wallis Wilcoxon rank sum test. Differences were considered statistically significant at $P<0.05$. Risk factors for surgery, death, and relapse were measured using Cox proportional hazard models for 
clustered data. Age group, gender, location and behaviour, nutrition status and treatment were included, and factors with a $P<0.05$ in univariate analysis were included in multivariate marginal Cox proportional hazard regression to create the adjusted model and their corresponding hazard ratio (HR) and 95\% CI (confidence interval). Cumulative probabilities of death, surgery and relapse rate in various age groups were calculated using the Kaplan-Meier method. SPSS 19 (Chicago, IL) was used for statistical analyses. GraphPad Prism 5 was used for Kaplan-Meier pictures.

\section{Results}

\section{Patient characteristics}

A total of 143 IBD patients (113 CD and $30 \mathrm{UC}$ ) aged under 17 years old were followed for a total of 404.08 person-years with a median follow-up duration of 26 months (range, 0-175 months). The median age at diagnosis was 9 years old. The youngest patient was 2 months old and the oldest was 16 years old. A total of 119 (83.2\%) patients were from other provinces (19 provinces) and $64(44.8 \%)$ patients were referred from other hospitals. There were 14 patients confirmed to have monogenic diseases and 13 of these had IL-10 receptor A (IL-10 RA) defects; they were all younger than 3 years old at the time of diagnosis. The mutations of four patients were homozygous, while the others were compound heterozygotes. Eight mutation sites were found; according to the guidelines for the interpretation of sequence variants by the ACMG (American College of Medical Genetics) [19], six sites were classified as pathogenic (p.R101W, p.T179 T, p.R117H, p.G141R, p.W424X and p.R165X) and two were classified into likely pathogenic (p.V100G and p.Y64C). One five-year-old patient was diagnosed as having GSD Ib (compound heterozygote of SLC37A4, two pathogenic sites) prior to IBD diagnosis. Family history of IBD was identified in six patients, and four of these had IL-10 RA defects. No consanguinity of parents was found in any patient.

\section{Clinical manifestations}

Table 1 shows the clinical manifestations of all groups of patients with three different ages. The findings indicated that clinical manifestations varied according to age. The percentage of diarrhoea and blood in stool were relatively high in the $0-2$ y group. Other systemic complications, including fever (73.5\%), anaemia (76.5\%), and growth impairment (55.9\%) were also commonly found in this group.

\section{Classification and location of the disease}

Paris classification of $\mathrm{UC}$ and $\mathrm{CD}$ at diagnosis is shown in Table 2. The location of $\mathrm{CD}$ varied according to age. The lesions were located mainly in L2 (colonic) in the $0-2$ y group; lesions were located mainly in L3

Table 1 Patient characteristics and clinical manifestations at diagnosis of different age groups

\begin{tabular}{|c|c|c|c|c|}
\hline Characteristics & $0-2 y$ & $3-9 y$ & $10-16 y$ & $P$ value \\
\hline Number (\%) & $34(23.8)$ & $46(32.2)$ & $63(44.0)$ & \\
\hline Male sex, n (\%) & $24(70.6)$ & $28(60.9)$ & $37(58.7)$ & 0.50 \\
\hline Diagnosis CD, n (\%) & $30(88.2)$ & $31(67.4)$ & $52(82.5)$ & 0.05 \\
\hline Genetics disease, n (\%) & $13(38.2)$ & $1(2.2)$ & $0(0.0)$ & $<0.01$ \\
\hline Family history of IBD, $\mathrm{n}(\%)$ & $5(14.7)$ & $1(2.2)$ & $0(0.0)$ & $<0.01$ \\
\hline Median time from symptom onset to diagnosis, mo (IQR) & $5(9.3)$ & $4(10.3)$ & $4.5(8.0)$ & 0.41 \\
\hline Median duration of follow-up period, mo (IQR) & $9(22.3)$ & $38(45.0)$ & $31(46.0)$ & $<0.01$ \\
\hline \multicolumn{5}{|l|}{ Symptoms n (\%) } \\
\hline Abdominal pain & $N / A^{a}$ & $35(76.1)$ & $49(77.8)$ & 0.84 \\
\hline Diarrhoea & $32(94.1)$ & $36(78.3)$ & $38(60.3)$ & $<0.01$ \\
\hline Blood in stool & $26(76.5)$ & $30(65.2)$ & $30(47.6)$ & 0.02 \\
\hline Oral ulcer & $7(20.6)$ & $5(10.9)$ & $13(20.6)$ & 0.36 \\
\hline Fever & $25(73.5)$ & $21(45.7)$ & $21(33.3)$ & $<0.01$ \\
\hline Anaemia & $26(76.5)$ & $30(65.2)$ & $41(65.1)$ & 0.47 \\
\hline weight $<-2 S D$ & $16(47.1)$ & $8(17.4)$ & $10(15.9)$ & $<0.01$ \\
\hline Growth impairment & 19 (55.9) & $18(39.1)$ & $13(20.6)$ & $<0.01$ \\
\hline limitation of activities & $17(50)$ & $13(28.3)$ & $14(22.2)$ & $<0.01$ \\
\hline Joints & $0(0)$ & $5(10.9)$ & $1(1.6)$ & 0.02 \\
\hline Skin & $2(5.9)$ & $1(2.2)$ & $1(1.6)$ & 0.50 \\
\hline
\end{tabular}

${ }^{a}$ As the presence of abdominal pain in younger children is very difficult to identify, we did not calculate the numbers of $0-2$ y group and only compared the other two groups 
Table 2 Paris phenotype and disease activity at diagnosis of different age groups

\begin{tabular}{|c|c|c|c|c|}
\hline & $0-2 y$ & $3-9 y$ & $10-16 y$ & $P$ value \\
\hline \multicolumn{5}{|l|}{ UC disease extent, n (\%) } \\
\hline E1 proctitis & $0(0)$ & $2(13.3)$ & $1(9.1)$ & \multirow[t]{4}{*}{0.80} \\
\hline E2 left-sided colitis & $1(25.0)$ & $5(33.4)$ & $3(27.3)$ & \\
\hline E3 extensive colitis & $2(50.0)$ & $2(13.3)$ & $2(18.2)$ & \\
\hline E4 pancolitis & $1(25.0)$ & $6(40.0)$ & $5(45.4)$ & \\
\hline severe (PUCAI $\geq 65$ ) & $0(0)$ & $3(20.0)$ & $3(27.3)$ & 0.35 \\
\hline \multicolumn{5}{|l|}{ CD disease location, $\mathrm{n}(\%)$} \\
\hline L1: terminal ileum & $2(6.7)$ & $4(12.9)$ & $12(23.1)$ & \multirow[t]{3}{*}{$<0.01$} \\
\hline L2: colonic & $20(66.6)$ & $5(16.1)$ & $6(11.5)$ & \\
\hline L3: ileocolonic & $8(26.7)$ & $22(71.0)$ & $33(63.5)$ & \\
\hline \multicolumn{5}{|l|}{ Upper gastrointestinal, n (\%) } \\
\hline$\llcorner 4 a+b:$ & 0 & 0 & $7(13.5)$ & \multirow[t]{3}{*}{0.03} \\
\hline$\llcorner 4 a$ & $4(13.3)$ & $8(25.8)$ & $13(25.0)$ & \\
\hline$\llcorner 4 \mathrm{~b}$ & $1(3.3)$ & $1(3.2)$ & $1(1.9)$ & \\
\hline \multicolumn{5}{|l|}{ CD disease behaviour, n (\%) } \\
\hline B1: non-stricturing, non-penetrating & $10(33.3)$ & $15(48.4)$ & $23(44.2)$ & \multirow[t]{4}{*}{0.04} \\
\hline B2: stricturing & $13(43.3)$ & $8(25.8)$ & $27(51.9)$ & \\
\hline B3: penetrating & $5(16.7)$ & $7(22.6)$ & $1(1.9)$ & \\
\hline B2B3: stricturing and/or penetrating & $2(6.7)$ & $1(3.2)$ & $1(1.9)$ & \\
\hline P: perianal & $23(76.7)$ & $6(19.4)$ & $19(36.5)$ & $<0.01$ \\
\hline \multicolumn{5}{|l|}{ Disease activity (at the diagnosis) } \\
\hline PCDAI (mean \pm SD) & $50.9 \pm 12.3$ & $40.0 \pm 11.9$ & $35.4 \pm 12.4$ & $<0.01$ \\
\hline PUCAI (mean \pm SD) & $31.3 \pm 16.5$ & $44.0 \pm 18.4$ & $44.1 \pm 20.0$ & 0.46 \\
\hline
\end{tabular}

(ileocolonic) in groups 3-9 y and 10-16 y. Thirty-five of $113(31.0 \%)$ CD patients showed upper GI tract lesions based on macroscopic appearance of mucosal ulceration or bowel wall thickening on radiography, and there was one 16-year-old patient with an upper GI lesion only, without colonic or ileocaecal lesions. The behaviour of disease also differed amongst groups. The $0-2$ y group showed such lesions as B2 or B2B3 at relatively high percentages. The disease activity was higher in the $0-2 \mathrm{y}$ group than in others at the time of diagnosis.

\section{Medical treatment}

The treatment of IBD followed a standardized protocol for patients according to the guidelines as described [20,21]. Induction therapy and maintenance therapy of the first year is displayed in Table 3. Two infantile patients after colectomy and colostomy were remission with total enteral nutrition (TEN). The patients with GSD Ib were treated with granulocyte colony-stimulating factor (G-CSF) and mesalazine. Forty-two (29.4\%) patients were steroid-dependent. Most patients received antibiotics as necessary during the course. Supportive treatments, including parenteral or enteral nutrition, immune globulin, albumin, transfusion with concentrated red cells, were given as necessary.
Table 3 Main medical treatment of CD and UC

\begin{tabular}{llll}
\hline Treatment & \multicolumn{3}{l}{ Number of patients (\%) } \\
\cline { 2 - 4 } & CD $(n=113)$ & UC $(n=30)$ & IBD (n=143) \\
\hline Induction therapy & & & \\
Corticosteroids & $57(50.4)$ & $18(60.0)$ & $75(52.4)$ \\
Mesalazine & $29(25.7)$ & $25(83.3)$ & $54(37.8)$ \\
Biological agent & $65(45.5)$ & $5(16.7)$ & $70(49.0)$ \\
Thalidomide & $14(12.4)$ & $3(10.0)$ & $17(11.9)$ \\
Maintenance therapy & & & \\
Azathioprine & $54(47.8)$ & $6(20.0)$ & $60(42.0)$ \\
Biological agent & $48(42.5)$ & $2(6.7)$ & $50(35.0)$ \\
Thalidomide & $32(28.3)$ & $3(10.0)$ & $35(24.5)$ \\
Mesalazine & $23(20.4)$ & $21(70.0)$ & $44(30.8)$ \\
Methotrexate & $3(2.7)$ & 0 & $3(2.1)$ \\
Cyclosporine A & $2(1.8)$ & $0(0.0)$ & $2(1.4)$ \\
Total enteral nutrition & $2(1.8)$ & $0(0.0)$ & $2(1.4)$ \\
Corticosteroids & $31(27.4)$ & $11(36.7)$ & $42(29.4)$
\end{tabular}

${ }^{a}$ The data are from an analysis of the first year of maintenance therapy 


\section{Surgical treatment}

There were 15 (10.5\%) patients who underwent abdominal surgeries, including $14 \mathrm{CD}$ patients and $1 \mathrm{UC}$ patient. The surgeries were carried out in the median duration of 5 months after disease onset; 14/15 patients underwent surgery within 20 months, and the remaining patient had surgery at 190 months. Figure 1 shows the Kaplan-Meier curve of time from onset to colectomy within 10 years. There were three major indications: confirmed diagnosis with exploratory laparotomy (3/15, $20.0 \%)$, intestinal perforation surgery $(7 / 15,46.7 \%)$ and aggressive disease after medical treatment (5/15, 33.3\%). Cox univariate analysis showed that surgery was only associated with B3 behaviour (HR: 10.2; 95\% CI: 3.3531.36; $P<0.01$ ). Intestinal or ileocaecal segment resection was performed in all patients; $9 / 15$ patients underwent colostomy or ileostomy simultaneously. Up to the latest follow-up, one patient with perforation died after surgery; one patient who underwent re-anastomosis of the bowel 5 months after colostomy died of sepsis after relapse. One patient had persistent disease activity after reconnection of the bowels. Six patients went into remission after colostomy, including two patients with TEN and others with medical therapy. The others were managed with medical treatment after surgery.

\section{Death analysis}

Seventeen patients (11.9\%) died, all of whom were CD patients. The characteristics of these patients are listed in Table 4. The median diagnosis age was 1 year old (range, 0.16-5 years old). The median time from diagnosis to death was 3.7 months (range, 0.4-43.7 months). Fourteen patients died of various complications of $\mathrm{CD}$, the majority from serious infections such as sepsis, while one patient died of sepsis after UCBT. Three died of intestinal perforation with or without surgery. Cox univariate analysis

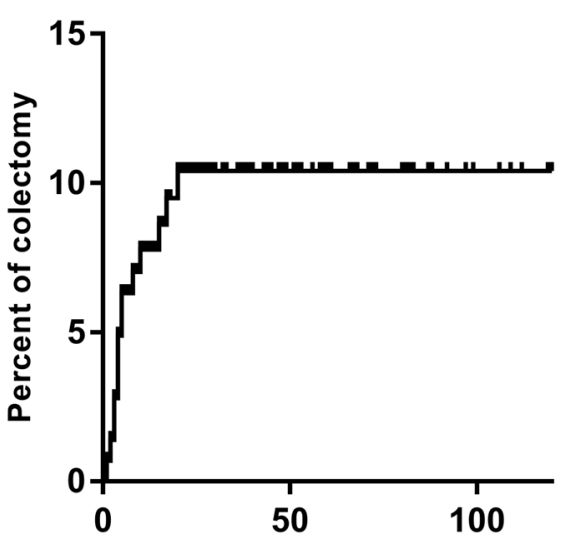

Months from onset to colectomy within 10 years

Fig. 1 Kaplan-Meier curve of time from onset to colectomy within 10 years follow-up showed that the death of CD patients was associated with age, perianal disease, B3 behaviour and $\mathrm{z}$-value of weight $<-2(P<0.01)$. Further multivariate analysis clearly suggested that age $0-2 \mathrm{y}$ and B3 behaviour were risk factors for death (Table 5). Figure 2 shows the cumulative survival rates of various age groups. There was no difference in mortality between patients with or without gene mutations in the $0-2$ y group.

\section{Relationship between sustained remission and phenotype of the disease}

Based on follow-up data, there were 52 (36.4\%) patients achieving sustained remission. There were 34 (23.8\%) patients with persistent index activity after the first three-month treatment. Fifty-seven (39.8\%) patients relapsed, and $27(47.6 \%)$ of these relapsed within 1 year of diagnosis. The cumulative sustained remission rates are shown in Fig. 3. The remission varied amongst the age groups. Cox univariate analysis indicated that the relapse of CD was associated with age, perianal disease, B3 behaviour, z-value of weight $<-2$ and steroid dependency. Further multivariate analysis suggested that age group $0-2$ y, B3 behaviour and steroid dependency were risk factors (Table 6). There was no difference of remission between patients with or without gene mutations in the $0-2$ y group.

\section{Discussion}

In this study, we analysed the relationship between disease phenotype and prognosis of paediatric inflammatory bowel disease in China. Younger patients may have extensive and aggressive disease. In the present study, $56 \%$ of paediatric IBD patients were younger than 10 years and $23.8 \%$ patients were younger than 3 years old. By contrast, the rate was quite low in a study carried out in Italy in which the VEO-IBD (0-3 y) was only 4\%; however, the fundamental difference was that patients with genetic defects were excluded [22]. In addition, the proportion of patients younger than 10 years old were also higher than in other studies (23.2-50\%) [22-25]. The explanation may be that, as a hospital specializing in refractory IBD, we observed more refractory patients who were recruited for this study and the patients recruited were much younger.

DNA sequencing tests for VEO-IBD patients were performed in the current study since 2012, and we found that $58.3 \%$ of the tested patients had monogenetic disorders with the gene mutation on IL-10 receptor A (IL-10RA). Glocker et al. first reported in 2009 that the mutation of IL-10 receptor caused IBD [26]; since then, IL-10 receptor defects have drawn much attention by paediatric IBD researchers worldwide [27, 28]. It is interesting that most studies in East Asia including our results pointed out the dominance of IL-10RA mutations in IBD patients. By contrast, based on the European data, the numbers of patients 
Table 4 Characteristics and clinical manifestations of patients who died

\begin{tabular}{|c|c|c|c|c|c|c|c|c|c|c|}
\hline No. & $\begin{array}{l}\text { Genetic } \\
\text { Test }\end{array}$ & $\begin{array}{l}\text { Age of } \\
\text { diagnosis (y) }\end{array}$ & $\begin{array}{l}\text { Initial } \\
\text { presentation }\end{array}$ & Phenotype & Family history & Medication & Surgery & Cause of death & $\begin{array}{l}\text { Months from } \\
\text { diagnosis } \\
\text { to death }\end{array}$ & $\begin{array}{l}\text { Year of } \\
\text { death }\end{array}$ \\
\hline 1 & NA & 3 & $\begin{array}{l}\text { Abdominal } \\
\text { pain, fever }\end{array}$ & $\mathrm{B} 3+\mathrm{P}$ & None & CS & $\begin{array}{l}\text { Colectomy and } \\
\text { enterostomy }\end{array}$ & $\begin{array}{l}\text { Intestinal } \\
\text { perforation }\end{array}$ & 3.2 & 2007 \\
\hline 2 & NA & 2.3 & $\begin{array}{l}\text { Diarrhoea, } \\
\text { Blood in stool }\end{array}$ & B2 & None & CS & - & Infection & 1.5 & 2007 \\
\hline 3 & NA & 5 & Diarrhoea & $B 3+P$ & None & CS, MES & - & Infection & 11.2 & 2009 \\
\hline 4 & NA & 0.6 & Diarrhoea & $\mathrm{B} 1+\mathrm{P}$ & None & IFX, CS & - & Infection & 4.2 & 2010 \\
\hline 5 & NA & 2 & Diarrhoea & $\mathrm{B} 2+\mathrm{P}$ & $\begin{array}{l}\text { A brother died } \\
\text { of diarrhoea }\end{array}$ & IFX, CS & Enterostomy & Infection & 5.0 & 2011 \\
\hline 6 & NA & 1 & Diarrhoea & $\mathrm{B} 2 \mathrm{~B} 3+\mathrm{P}, \mathrm{L} 4 \mathrm{a}$ & None & CS & - & Infection & 0.6 & 2011 \\
\hline 7 & NA & 1.5 & $\begin{array}{l}\text { Diarrhoea, } \\
\text { fever }\end{array}$ & $B 2+P$ & None & $\mathrm{CS}, \mathrm{AZA}$ & - & Infection & 43.7 & 2015 \\
\hline 8 & NA & 0.3 & $\begin{array}{l}\text { Diarrhoea, } \\
\text { fever }\end{array}$ & $\mathrm{B} 3+\mathrm{P}$ & None & CS & - & Infection & 2.0 & 2012 \\
\hline 9 & ND & 1.5 & $\begin{array}{l}\text { Diarrhoea, } \\
\text { fever }\end{array}$ & $\mathrm{B} 2+\mathrm{P}$ & None & IFX, CS, THD & - & $\begin{array}{l}\text { Intestinal } \\
\text { perforation }\end{array}$ & 26.3 & 2014 \\
\hline 10 & IL-10RA & 0.83 & $\begin{array}{l}\text { Diarrhoea, } \\
\text { fever }\end{array}$ & $B 1+P$ & None & IFX, CS, THD & - & Infection & 6.1 & 2014 \\
\hline 11 & NA & 0.83 & $\begin{array}{l}\text { Diarrhoea, } \\
\text { fever }\end{array}$ & $B 2 B 3+P, L 4 b$ & None & CS & - & $\begin{array}{l}\text { Intestinal } \\
\text { perforation }\end{array}$ & 0.5 & 2014 \\
\hline 12 & NA & 0.16 & $\begin{array}{l}\text { Diarrhoea, } \\
\text { fever }\end{array}$ & $\mathrm{B} 3+\mathrm{P}$ & None & CS & - & Infection & 2.1 & 2015 \\
\hline 13 & ND & 2.5 & $\begin{array}{l}\text { Diarrhoea, } \\
\text { fever }\end{array}$ & $\mathrm{B} 2+\mathrm{P}$ & None & IFX, CS & - & Infection & 3.7 & 2014 \\
\hline 14 & IL-10RA & 0.8 & $\begin{array}{l}\text { Diarrhoea, } \\
\text { fever }\end{array}$ & $B 3+P$ & No.17's sister & $\mathrm{THD}$ & - & Infection & 1.6 & 2014 \\
\hline 15 & ND & 1 & $\begin{array}{l}\text { Diarrhoea, } \\
\text { fever }\end{array}$ & $\mathrm{B} 2+\mathrm{P}$ & None & CS & - & Infection & 10.4 & 2016 \\
\hline 16 & IL-10RA & 1.67 & $\begin{array}{l}\text { Diarrhoea, } \\
\text { fever }\end{array}$ & $\mathrm{B} 1+\mathrm{P}, \mathrm{L} 4 \mathrm{a}$ & None & $\begin{array}{l}\text { Antibiotics } \\
\text { only }^{\mathrm{a}}\end{array}$ & - & Infection & 0.4 & 2016 \\
\hline 17 & IL-10RA & 0.58 & $\begin{array}{l}\text { Diarrhoea, } \\
\text { fever }\end{array}$ & B1 & $\begin{array}{l}\text { No } 14 \text { 's younger } \\
\text { brother }\end{array}$ & UCBT & - & $\begin{array}{l}\text { Infection } \\
\text { after UCBT }\end{array}$ & 9.5 & 2016 \\
\hline
\end{tabular}

AZA azathioprine, CS corticosteroids, EN enteral nutrition, IFX infliximab, MES mesalazine, NA not available, THD thalidomide, ND not detected, UCBT umbilical cord blood trans-plantation

${ }^{a}$ Other patients may also use antibiotics but not list in the table

with IL-10RA and IL-10 receptor B (IL-10RB) mutation were somewhat equivalent. In addition, our data demonstrated that none of our patients suffered from lymphoma and no parents were consanguineous; these observations are also different from those of the European survey [28]. Because of the high percentage of positive findings, one would speculate that there should be more patients with gene mutations related to IBD in those diagnosed before 2012 who were not examined by the NGS test. Furthermore, some studies demonstrated that many monogenetic disorders may cause IBD [29]. We had a patient who developed IBD secondary to GSD Ib, something that has not been reported in China before. It is noteworthy that 77\% of GSD Ib patients may have IBD, and for these patients, recommended treatment is with G-CSF and mesalazine rather than with steroids [30,31]. We also diagnosed two younger patients with diarrhoea as having chronic granulomatous disease (CYBB mutation) and hyper-IgM syndrome (CD40LG mutation). Both of which have been reported as monogenetic disorders causing IBD. Since they did not have typical IBD endoscopic and pathological manifestations, these two patients were not included in the study. Another study also reported mutations in EPCAM, TNFAIP3 and LRBA in China. However, based on all the data, it has been confirmed that IL-10 RA may be the main mutation in China [32, 33].

The clinical manifestations and phenotypes of diseases were analysed for patients diagnosed in the current study. Patients in the $0-2$ y group commonly manifested systemic symptoms such as fever, weight loss and limitation of activity, colonic lesions, strictures and perianal disease; this was similar to what was reported in other studies [34]. It was reported that patients usually had accompanying extra-intestinal symptoms of joints, skin, 
Table 5 Univariable and multivariable analyses of clinical variables influencing death in CD

\begin{tabular}{|c|c|c|c|c|c|c|}
\hline \multirow[t]{2}{*}{ Variables } & \multicolumn{3}{|c|}{ Univariable analysis } & \multicolumn{3}{|c|}{ Multivariable analysis (significant in univariate) } \\
\hline & $\mathrm{HR}$ & $95 \% \mathrm{Cl}$ & $P$ value & $\mathrm{HR}$ & $95 \% \mathrm{Cl}$ & $P$ value \\
\hline \multicolumn{7}{|l|}{ Age } \\
\hline $3-9$ y vs $0-2$ y & 0.09 & $0.02-0.38$ & $<0.01$ & 0.11 & $0.18-0.61$ & 0.01 \\
\hline $10-16$ y vs $0-2$ y & 0.01 & $0.00-0.00$ & 0.93 & 0 & $0-0$ & 0.92 \\
\hline \multicolumn{7}{|l|}{ Sex } \\
\hline female vs male & 0.35 & $0.10-1.22$ & 0.10 & & & \\
\hline \multicolumn{7}{|l|}{ Disease location } \\
\hline L2 vs L1 & 7.15 & $0.92-55.37$ & 0.06 & & & \\
\hline L3 vs L1 & 1.40 & $0.16-11.94$ & 0.76 & & & \\
\hline L4 vs no L4 & 0.48 & $0.14-1.68$ & 0.25 & & & \\
\hline Perianal disease vs not & 12.37 & $2.81-54.80$ & $<0.01$ & 3.45 & $0.69-17.28$ & 0.13 \\
\hline Behaviour B2 vs not & 1.02 & $0.39-2.64$ & 0.97 & & & \\
\hline Behaviour B3 vs not & 5.23 & $1.98-13.79$ & $<0.01$ & 4.83 & $1.57-14.87$ & $<0.01$ \\
\hline Weight $<-2$ SD vs not & 5.96 & $2.20-16.20$ & $<0.01$ & 1.51 & $0.51-4.52$ & 0.46 \\
\hline Growth impairment vs not & 2.01 & $0.77-5.29$ & 0.16 & & & \\
\hline Top-down treatment vs not & 0.40 & $0.09-1.74$ & 0.22 & & & \\
\hline Steroid dependency vs not & 1.75 & $0.67-4.60$ & 0.26 & & & \\
\hline
\end{tabular}

liver, and eyes with percentages as high as $10-20 \%$ [23, 35]; however, few patients in the current study developed these extra-intestinal symptoms. It is worth noting that there were two patients with histories of juvenile rheumatoid arthritis (JIA) in the study; further investigation is needed to elucidate whether JIA and IBD are associated with the same pathogenesis.

Our centre has a standardized protocol of treatments for IBD patients. Of the total, $76.2 \%$ went into remission or improved after induction therapy. However, patients younger than 3 years old may relapse or suffer from various complications, possibly leading to a poor prognosis. Our findings indicated that infantile patients, penetrating lesions and steroid dependency were risk factors for poor

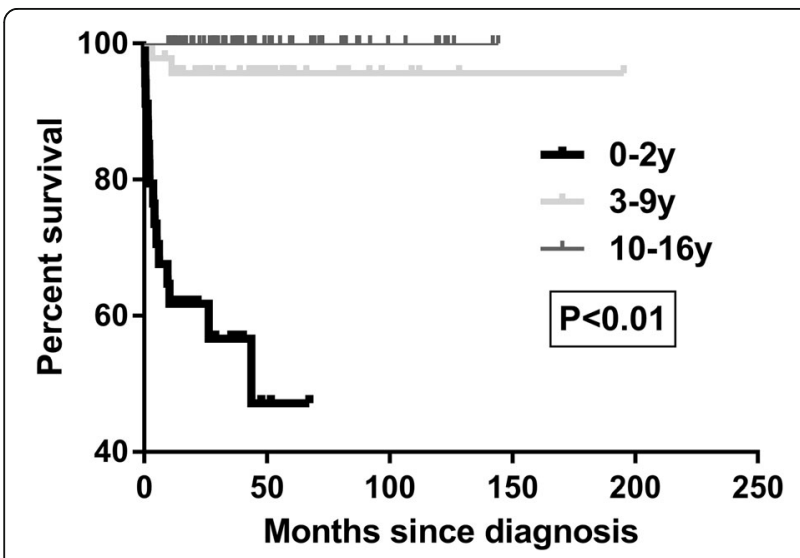

Fig. 2 Kaplan-Meier curves showing time from diagnosis to death. Log rank test for equality of survival curves, $P<0.01$ prognosis, a finding that accorded with the consensus guidelines of ECCO/ESPGHAN [20].

Death reports were relatively high in this study, and all the deaths were in patients $<6$ years old with CD. Most of these were very sick when they were recruited at the centre and half of them died within the first 3 months after diagnosis. Some patients responded to the treatment of IBD but developed infections and died unexpectedly. Some deaths were confirmed as being associated with IL-10RA defects. It was reported that IL-10RA mutations affected immune function, and patients with IL-10RA mutations may have a poorer prognosis [13]. Fortunately, IL-10RA and IL-10RB mutations can now be cured through haematopoietic stem cell transplantation $[9,36]$.

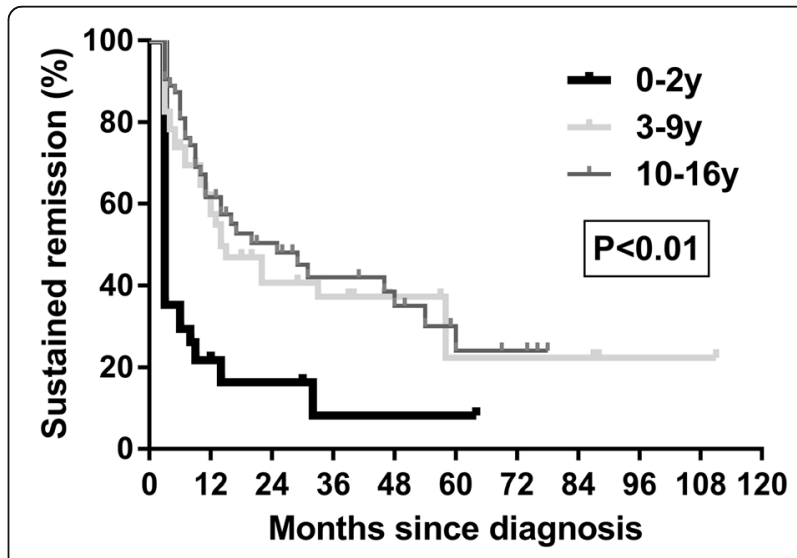

Fig. 3 Kaplan-Meier curves showing time from diagnosis to relapse. Log rank test for equality of survival curves, $P<0.01$ 
Table 6 Univariable and multivariable analyses of clinical variables influencing relapse in CD

\begin{tabular}{|c|c|c|c|c|c|c|}
\hline \multirow[t]{2}{*}{ Variables } & \multicolumn{3}{|c|}{ Univariable analysis } & \multicolumn{3}{|c|}{ Multivariable analysis (significant in univariate) } \\
\hline & $\mathrm{HR}$ & $95 \% \mathrm{Cl}$ & $P$ value & $\mathrm{HR}$ & $95 \% \mathrm{Cl}$ & $P$ value \\
\hline \multicolumn{7}{|l|}{ Age } \\
\hline $3-9$ y vs $0-2$ y & 0.25 & $0.14-0.48$ & $<0.01$ & 0.26 & $0.13-0.53$ & $<0.01$ \\
\hline $10-16$ y vs $0-2$ y & 0.20 & $0.11-0.36$ & $<0.01$ & 0.23 & $0.12-0.44$ & $<0.01$ \\
\hline \multicolumn{7}{|l|}{ Sex } \\
\hline female vs male & 0.84 & $0.52-1.36$ & 0.47 & & & \\
\hline \multicolumn{7}{|l|}{ Disease location } \\
\hline L2 vs L1 & 2.18 & $0.98-4.84$ & 0.06 & & & \\
\hline L3 vs L1 & 1.29 & $0.61-2.77$ & 0.51 & & & \\
\hline L4 vs no L4 & 0.89 & $0.54-1.46$ & 0.64 & & & \\
\hline Perianal disease, yes vs no & 1.59 & $1.00-2.53$ & 0.048 & 1.13 & $0.68-1.88$ & 0.63 \\
\hline Behaviour B2 vs not & 1.04 & $0.66-1.64$ & 0.87 & & & \\
\hline Behaviour B3 vs not & 2.08 & $1.15-3.77$ & 0.02 & 1.96 & $1.01-3.81$ & 0.046 \\
\hline Weight $<-2$ SD vs not & 1.71 & $1.04-2.82$ & 0.04 & 0.96 & $0.54-1.69$ & 0.88 \\
\hline Growth impairment vs not & 1.31 & $0.83-2.09$ & 0.25 & & & \\
\hline Top-down treatment vs not & 0.69 & $0.40-1.21$ & 0.20 & & & \\
\hline Steroid dependency vs not & 2.26 & $1.40-3.64$ & $<0.01$ & 1.88 & $1.16-3.06$ & 0.01 \\
\hline
\end{tabular}

Based on our follow-up data, patients with a poor response to medicine would improve after colectomy, especially combined with colostomy. It was reported that all patients with IL-10RA and IL-10RB mutations need surgical interventions, including partial or subtotal colectomy. This may prolong survival time, but cannot help patients achieve remission [37]. Our experience showed that colostomy might be an effective therapy that can maintain clinical remission but cannot lead to mucosal healing. As some patients refused to have colostomy when advised, the reported percentage of surgery may be lower than medically necessary. Because a limited number of patients had long follow-up of colostomy, more clinical observation is required.

Our results have some limitations. As a hospital specializing in refractory IBD, the clinical features of patients presenting with refractory IBD differ from those of the general population. This may cause referral bias. A national IBD network should be set up to recruit more patients within the Chinese population. Another limitation was that, as a retrospective study, non-standardized documentation may have resulted in the inability to determine disease prognosis with various treatments. Furthermore, antibiotics and supportive treatment including parenteral or enteral nutrition were not recorded in detail. The potential variability in treatment practices could impact outcomes. It is worthwhile to set up a randomized controlled trial to analyse the long-term efficacy and safety of these medicines in different age groups. It is worth noting that the development of diagnostic methods during our study period may have affected the evaluation and treatments in the study. For example, genetic testing may have impacted the rate of detection of monogenic disease and changes in investigations (MRE and capsule endoscopy) over the study period, possibly impacting determination of the extent of small bowel Crohn's disease.

\section{Conclusions}

We determined that age was the major factor determining the various clinical manifestations and prognoses for IBD patients. Infantile IBD may be caused by monogenic defects, particularly IL-10 RA mutations. Colostomy can improve clinical symptoms, but haematopoietic stem cell transplantation might cure these patients. NGS should be performed for each VEO-IBD, especially for infants. It is necessary to incorporate genetic testing into medical insurance plans and to regard it as a routine examination. This will improve the diagnosis and treatment of VEO-IBD in China.

\section{Abbreviations}

ACMG: American College of Medical Genetics; AZA: Azathioprine; CD: Crohn's disease; Cl: Confidence interval; CS: Corticosteroids; EN: Enteral nutrition; ESR: Erythrocyte sedimentation rate; G-CSF: Granulocyte colony-stimulating factor; Gl: Gastrointestinal; GSD: Glycogen storage disease; HR: Hazard ratio; IBD: Inflammatory bowel disease; IBD-U: IBD-unclassified; IFX: Infliximab; IL-10 RA: IL-10 receptor A; IL-10RB: IL-10 receptor B; IQR: Interquartile range; JIA: Juvenile rheumatoid arthritis; MDT: Multi-disciplinary team; MES: Mesalazine; MTX: Methotrexate; NA: Not available; ND: Not detected; NGS: Next generation sequencing; PCDAl: Paediatric Crohn's Disease Activity Index; PUCAl: Paediatric Ulcerative Colitis Activity Index; SD: Standard deviation; TEN: Total enteral nutrition; THD: Thalidomide; UC: Ulcerative colitis; UCBT: Umbilical cord blood trans-plantation; VEO-IBD: Very early onset IBD; WES: Whole exome sequencing; y: Years 


\section{Acknowledgements}

We are grateful to our colleagues in the Department of Paediatrics, Ruijin Hospital, Ruijin Hospital North for their help with the study. We thank Prof. Hong-hua Mu and Cornnor Meaney for their English language editing. We thank all authors who have read and approved the final manuscript.

\section{Funding}

This work was supported by National Nature Science Foundation of China under Grant No. 81400588 and IPSEN Fund for the research of diarrhoea under Grant No. IDF-2015-02.

\section{Availability of data and materials}

The datasets generated during and/or analysed during the current study are available from the corresponding author on reasonable request.

\section{Authors' contributions}

WXQ, XCD and YYZ designed this study; WXQ and XX drafted the manuscript. $X Y$ performed next generation sequencing; $Y Y, S C Y, G Y, X X$ and $G L$ collected and interpreted the data; ZT, WXJ and GSS statistically analysed the data. All authors have read and approved the final version to be published.

\section{Ethics approval and consent to participate}

The study was reviewed and approved by the ethics committee of Ruijin Hospital, Shanghai Jiao Tong University School of Medicine. Verbal and written consent was obtained from parents or legal guardians of the patients at diagnosis or follow-up.

\section{Consent for publication}

Not applicable.

\section{Competing interests}

The authors declare that they have no competing interest.

\section{Publisher's Note}

Springer Nature remains neutral with regard to jurisdictional claims in published maps and institutional affiliations.

\section{Author details}

'Department of Paediatrics, Ruijin Hospital, Shanghai Jiao Tong University, School of Medicine, No. 197, Rui Jin Er Road, Shanghai 200025, China. ${ }^{2}$ Department of Paediatrics, Ruijin Hospital North, Shanghai Jiao Tong University, School of Medicine, Shanghai 201821, China. ${ }^{3}$ Department of Gastroenterology, Ruijin Hospital, Shanghai Jiao Tong University, School of Medicine, Shanghai 200025, China. ${ }^{4}$ Department of Biostatistics, Shanghai Jiao Tong University, School of Medicine, Shanghai 200025, China.

\section{Received: 28 April 2018 Accepted: 6 July 2018}

\section{Published online: 12 July 2018}

\section{References}

1. Vernier-Massouille G, Balde M, Salleron J, Turck D, Dupas JL, Mouterde O, Merle V, Salomez JL, Branche J, Marti R, et al. Natural history of pediatric Crohn's disease: a population-based cohort study. Gastroenterology. 2008; 135(4):1106-13.

2. Wang $X Q$, Zhang $Y, X u C D$, Jiang $L R$, Huang $Y$, Du HM, Wang XJ. Inflammatory bowel disease in Chinese children: a multicenter analysis over a decade from Shanghai. Inflamm Bowel Dis. 2013;19(2):423-8.

3. Van Limbergen J, Russell RK, Drummond HE, Aldhous MC, Round NK, Nimmo ER, Smith L, Gillett PM, McGrogan P, Weaver LT, et al. Definition of phenotypic characteristics of childhood-onset inflammatory bowel disease. Gastroenterology. 2008;135(4):1114-22.

4. Kugathasan S, Cohen S. Searching for new clues in inflammatory bowel disease: tell tales from pediatric IBD natural history studies. Gastroenterology. 2008;135(4):1038-41.

5. Maisawa S, Sasaki M, Ida S, Uchida K, Kagimoto S, Shimizu T, Yoden A. Characteristics of inflammatory bowel disease with an onset before eight years of age: a multicenter epidemiological survey in Japan. J Gastroenterol Hepatol. 2013;28(3):499-504.

6. Levine A, Griffiths A, Markowitz J, Wilson DC, Turner D, Russell RK, Fell Ruemmele FM, Walters T, Sherlock M, et al. Pediatric modification of the
Montreal classification for inflammatory bowel disease: the Paris classification. Inflamm Bowel Dis. 2011:17(6):1314-21.

7. Bianco AM, Girardelli M, Tommasini A. Genetics of inflammatory bowel disease from multifactorial to monogenic forms. World J Gastroenterol. 2015;21(43):12296-310

8. Begue B, Verdier J, Rieux-Laucat F, Goulet O, Morali A, Canioni D, Hugot JP, Daussy C, Verkarre V, Pigneur B, et al. Defective IL10 signaling defining a subgroup of patients with inflammatory bowel disease. Am J Gastroenterol. 2011;106(8):1544-55.

9. Uhlig HH, Schwerd T, Koletzko S, Shah N, Kammermeier J, Elkadri A, Ouahed J. Wilson DC, Travis SP, Turner D, et al. The diagnostic approach to monogenic very early onset inflammatory bowel disease. Gastroenterology. 2014:147(5):990-1007. e1003

10. Okou DT, Kugathasan S. Role of genetics in pediatric inflammatory bowel disease. Inflamm Bowel Dis. 2014:20(10):1878-84.

11. Levine A, Koletzko S, Turner D, Escher JC, Cucchiara S, de Ridder L, Kolho KL, Veres G, Russell RK, Paerregaard A, et al. ESPGHAN revised porto criteria for the diagnosis of inflammatory bowel disease in children and adolescents. J Pediatr Gastroenterol Nutr. 2014:58(6):795-806.

12. Ibd Working Group of the European Society for Paediatric Gastroenterology $H$, Nutrition. Inflammatory bowel disease in children and adolescents: recommendations for diagnosis-the Porto criteria. J Pediatr Gastroenterol Nutr. 2005:41(1):1-7.

13. Xiao $Y$, Wang $X Q$, Yu Y, Guo $Y, X u X$, Gong L, Zhou T, Li XQ, Xu CD. Comprehensive mutation screening for 10 genes in Chinese patients suffering very early onset inflammatory bowel disease. World J Gastroenterol. 2016;22(24):5578-88

14. Li Q, Lee CH, Peters LA, Mastropaolo LA, Thoeni C, Elkadri A, Schwerd T, Zhu J, Zhang B, Zhao Y, et al. Variants in TRIM22 that affect NOD2 signaling are associated with very-early-onset inflammatory bowel disease. Gastroenterology. 2016;150(5):1196-207

15. Uhlig HH, Schwerd T. From genes to mechanisms: the expanding spectrum of monogenic disorders associated with inflammatory bowel disease. Inflamm Bowel Dis. 2016:22(1):202-12

16. Hyams J, Markowitz J, Otley A, Rosh J, Mack D, Bousvaros A, Kugathasan S, Pfefferkorn M, Tolia V, Evans J, et al. Evaluation of the pediatric Crohn disease activity index: a prospective multicenter experience. J Pediatr Gastroenterol Nutr. 2005:41(4):416-21.

17. Turner D, Hyams J, Markowitz J, Lerer T, Mack DR, Evans J, Pfefferkorn M, Rosh J, Kay M, Crandall W, et al. Appraisal of the pediatric ulcerative colitis activity index (PUCAI). Inflamm Bowel Dis. 2009;15(8):1218-23.

18. Coordinating Study Group of Nine Cities on Physical G, Development of C Capital Institute of P. A national survey on growth of children under 7 years of age in nine cities of China, 2005. Zhonghua Er Ke Za Zhi. 2007;45(8):609-14.

19. Richards S, Aziz N, Bale S, Bick D, Das S, Gastier-Foster J, Grody WW, Hegde

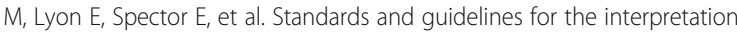
of sequence variants: a joint consensus recommendation of the American College of Medical Genetics and Genomics and the Association for Molecular Pathology. Genet Med. 2015;17(5):405-24.

20. Ruemmele FM, Veres G, Kolho KL, Griffiths A, Levine A, Escher JC, Amil Dias J. Barabino A, Braegger CP, Bronsky J, et al. Consensus quidelines of ECCO/ ESPGHAN on the medical management of pediatric Crohn's disease. J Crohns Colitis. 2014:8(10):1179-207.

21. Sandhu BK, Fell JM, Beattie RM, Mitton SG, Wilson DC, Jenkins H, lbd Working Group of the British Society of Paediatric Gastroenterology H, Nutrition. Guidelines for the management of inflammatory bowel disease in children in the United Kingdom. J Pediatr Gastroenterol Nutr. 2010;50(Suppl 1):S1-13.

22. Aloi M, Lionetti $P$, Barabino A, Guariso G, Costa S, Fontana M, Romano C, Lombardi G, Miele E, Alvisi P, et al. Phenotype and disease course of early-onset pediatric inflammatory bowel disease. Inflamm Bowel Dis. 2014;20(4):597-605.

23. Buderus S, Scholz D, Behrens R, Classen M, De Laffolie J, Keller KM, Zimmer KP, Koletzko S, Group C-GS. Inflammatory bowel disease in pediatric patients: characteristics of newly diagnosed patients from the CEDATAGPGE Registry. Dtsch Arztebl Int. 2015;112(8):121-7.

24. Gupta N, Bostrom AG, Kirschner BS, Cohen SA, Abramson O, Ferry GD, Gold BD, Winter HS, Baldassano RN, Smith T, et al. Presentation and disease course in early- compared to later-onset pediatric Crohn's disease. Am J Gastroenterol. 2008;103(8):2092-8.

25. Zhu L, Shi T, Zhong C, Wang Y, Chang M, Liu X. IL-10 and IL-10 recepto mutations in very early onset inflammatory bowel disease. Gastroenterology Res. 2017;10(2):65-9. 
26. Glocker EO, Kotlarz D, Boztug K, Gertz EM, Schaffer AA, Noyan F, Perro M, Diestelhorst J, Allroth A, Murugan D, et al. Inflammatory bowel disease and mutations affecting the interleukin-10 receptor. N Engl J Med. 2009;361(21): 2033-45.

27. Glocker EO, Kotlarz D, Klein C, Shah N, Grimbacher B. IL-10 and IL-10 receptor defects in humans. Ann N Y Acad Sci. 2011;1246:102-7.

28. Pigneur B, Escher J, Elawad M, Lima R, Buderus S, Kierkus J, Guariso G, Canioni D, Lambot K, Talbotec C, et al. Phenotypic characterization of very early-onset IBD due to mutations in the IL10, IL10 receptor alpha or beta gene: a survey of the Genius Working Group. Inflamm Bowel Dis. 2013; 19(13):2820-8

29. Christodoulou K, Wiskin AE, Gibson J, Tapper W, Willis C, Afzal NA, UpstillGoddard R, Holloway JW, Simpson MA, Beattie RM, et al. Next generation exome sequencing of paediatric inflammatory bowel disease patients identifies rare and novel variants in candidate genes. Gut. 2013;62(7):977-84.

30. Visser G, Rake JP, Fernandes J, Labrune P, Leonard JV, Moses S, Ullrich K, Smit GP. Neutropenia, neutrophil dysfunction, and inflammatory bowel disease in glycogen storage disease type Ib: results of the European Study on Glycogen Storage Disease type I. J Pediatr. 2000;137(2):187-91.

31. Dieckgraefe BK, Korzenik JR, Husain A, Dieruf L. Association of glycogen storage disease $1 \mathrm{~b}$ and Crohn disease: results of a North American survey. Eur J Pediatr. 2002;161(Suppl 1):S88-92.

32. Huang Z, Peng K, Li X, Zhao R, You J, Cheng X, Wang Z, Wang Y, Wu B, Wang $\mathrm{H}$, et al. Mutations in Interleukin-10 receptor and clinical phenotypes in patients with very early onset inflammatory bowel disease: a Chinese VEO-IBD collaboration group survey. Inflamm Bowel Dis. 2017:23(4):578-90.

33. Ye Z, Zhou Y, Huang Y, Wang Y, Lu J, Tang Z, Miao S, Dong K, Jiang Z. Phenotype and Management of Infantile-onset Inflammatory Bowel Disease: experience from a tertiary Care Center in China. Inflamm Bowel Dis. 2017; 23(12):2154-64.

34. Nambu R, Hagiwara S, Kubota M, Kagimoto S. Difference between early onset and late-onset pediatric ulcerative colitis. Pediatr Int. 2016;58(9):862-6.

35. Urlep D, Trop TK, Blagus R, Orel R. Incidence and phenotypic characteristics of pediatric IBD in northeastern Slovenia, 2002-2010. J Pediatr Gastroenterol Nutr. 2014;58(3):325-32.

36. Uhlig HH. Monogenic diseases associated with intestinal inflammation: implications for the understanding of inflammatory bowel disease. Gut. 2013;62(12):1795-805.

37. Engelhardt KR, Shah N, Faizura-Yeop I, Kocacik Uygun DF, Frede N, Muise AM, Shteyer E, Filiz S, Chee R, Elawad M, et al. Clinical outcome in IL-10- and IL-10 receptor-deficient patients with or without hematopoietic stem cell transplantation. J Allergy Clin Immunol. 2013;131(3):825-30

\section{Ready to submit your research? Choose BMC and benefit from:}

- fast, convenient online submission

- thorough peer review by experienced researchers in your field

- rapid publication on acceptance

- support for research data, including large and complex data types

- gold Open Access which fosters wider collaboration and increased citations - maximum visibility for your research: over $100 \mathrm{M}$ website views per year

At BMC, research is always in progress.

Learn more biomedcentral.com/submissions 